2014

\title{
A Connection of Central Significance: Sufficient Occupancy and Aboriginal Title
}

John J. Wilson

Follow this and additional works at: http://digitalcommons.osgoode.yorku.ca/olsrps

\section{Recommended Citation}

Wilson, John J., "A Connection of Central Significance: Sufficient Occupancy and Aboriginal Title" (2014). Osgoode Legal Studies Research Paper Series. 33.

http://digitalcommons.osgoode.yorku.ca/olsrps/33 


\section{OSGOODE HALL LAW SCHOOL LEGAL STUDIES RESEARCH PAPER SERIES}

Research Paper No. 58

Vol. 10/ Issue. 13/ (2014)

\section{A Connection of Central Significance: Sufficient Occupancy and Aboriginal Title}

John J Wilson

Editors:

Editor-in-Chief: Carys J. Craig (Associate Dean of Research \& Institutional Relations and Associate Professor, Osgoode Hall Law School, York University, Toronto)

Production Editor: James Singh (Osgoode Hall Law School, York University, Toronto) 
Osgoode Legal Studies Research Paper No. 58

Vol. 10/ Issue. 13/ (2014)

\title{
A Connection of Central Significance: Sufficient Occupancy and Aboriginal Title
}

\author{
John J Wilson
}

\begin{abstract}
: Aboriginal rights writ large.

\section{Keywords:}

Constitutional Law, Aboriginal Rights, Aboriginal Title

\section{Author(s):}

John J Wilson

Osgoode Hall Law School

York University, Toronto

E: johnwilson@osgoode.yorku.ca
\end{abstract}

This paper is an extended commentary on a recent British Columbia Court of Appeal Decision, William v British Columbia, 2012 BCCA 285. It rehearses and critiques the central debate between the appellant and respondent regarding the quality or character of physical occupation necessary to successfully ground an Aboriginal title claim under section 35 of the Constitution Act, 1982. Ultimately, it argues that the Court of Appeal erred in its endorsement of a "site-specific" understanding of sufficient occupancy, and further, that the central debate itself is orthogonal to the true concern underlying the occupancy requirement. It concludes with an alternative test for sufficient occupancy which is more consistent with the previous jurisprudence and the goals of Aboriginal title and Canadian 


\section{JOHN WILSON}

OSGOODE HALL LAW SCHOOL

MAY 2014

A Connection of Central Significance: Sufficiency of Occupancy and Aboriginal Title

In William v British Columbia, 2012 BCCA $285^{1}$, the British Columbia Court of Appeal is presented with two different interpretations of what satisfies the occupancy requirement of an Aboriginal title claim. At the time of William, the courts remained without clear direction, as the Supreme Court remained largely silent on the issue in Delgamuukw v British Columbia, ${ }^{2}$ the leading case on Aboriginal title writ large. As noted by Groberman J in William, the Delgamuukw court "does not fully address the quality of occupancy necessary to support a title claim."3 That is, although the Court in Delgamuukw makes clear that a claim for Aboriginal title requires physical occupation of the lands in question, it does not explicitly delineate the necessary or essential characteristics of that occupation. ${ }^{4}$ This lacuna persists in the most recent Supreme Court of Canada case regarding title, $R v$ Marshall; $R v$ Bernard. ${ }^{5}$

This lack of explicit guidance as to what will suffice for physical occupationand the resulting interpretive latitude-becomes a central issue in William. Both parties rely heavily on the following passage from Delgamuukw:

Physical occupation may be established in a variety of ways, ranging from the construction of dwellings through cultivation and enclosure of fields to

${ }^{1} 2012$ BCCA 285 [“William”]

2 [1997] 3 SCR 1010 ["Delgamuukw”]

${ }^{3}$ supra note 1 at para 220.

${ }^{4}$ See supra note 2 at para 149.

52005 SCC 43 [“Marshall; Bernard”] 
regular use of definite tracks of land for hunting, fishing, or otherwise exploiting its resources ${ }^{6}$

The parties offer their own interpretations of what kind of occupancy was contemplated in this passage. The appellant, Chief Roger William, forwards a more expanded understanding of sufficient occupancy akin to the one found by the Trial Judge, Vickers J. On this view, "regular" and not intense use is emphasized, such that title could be established not only through the occupation of settlements and areas cultivated for agriculture, but also through exclusive, regular use of hunting and fishing grounds. ${ }^{7}$ The appellant argued that this less demanding, regular use of defined hunting and fishing areas could grant title to those areas themselves. ${ }^{8}$ The Trial Judge accepted this argument, and dismissed the respondent's more restrictive "postage stamp" account, doing so because a narrow, site-specific account did not, in his view, do justice to the collective history of Aboriginal peoples:

The plaintiff characterizes the foregoing arguments of the defendants as a postage stamp approach to Aboriginal title. I think that is a fair description. There is no evidence to support a conclusion that Aboriginal people ever lived this kind of postage stamp existence. ${ }^{9}$

In contrast to the "regular" use account of the appellant, the respondents noted Delgamuukw's emphasis on "definite tracts" of land to argue for a "site-specific" model on which title could only be accorded to areas particularly delineated and intensely used. The Court of Appeal adopted this site-specific model, agreeing with the respondents and holding that Aboriginal title grounded in resource-exploitation could only be found in

\footnotetext{
${ }^{6}$ Supra note 2 at para 149.

${ }^{7}$ Tsilhqot'in Nation v. British Columbia, 2007 BCSC 1700 at para 684[“"Trial Judgment"].

${ }^{8}$ Ibid at paras 582-3.

${ }^{9}$ Ibid at para 610 .
} 
strictly defined, intensely used areas, such as particular hunting grounds, "salt licks, or "particular rocks or promontories used for netting salmon." ${ }^{10}$ In its reasons, the Court of Appeal also held that the appellant's position could be characterized fairly as "territorial," and that claims of this nature departed from what was contemplated as sufficient occupancy in Delgamuukw. Furthermore, it held that such 'territorial' claims were inconsistent with the overall rationale of Aboriginal title and the broader reconciliatory goal of Aboriginal rights writ large. ${ }^{11}$

The end result of this interpretive dilemma will have important jurisprudential consequences. As noted by the Court of Appeal itself, the William case is an “extraordinary one:" a tremendous amount of resources has been expended by both sides, leading to a vigorous, difficult, and complex history of litigation, and the construction of a "very complete record." $" 12$ For these reasons, the Court of Appeal describes it as being "in many respects a test case on the issue of Aboriginal title" presenting "a suitable vehicle for development of the law." ${ }^{13}$ The Court of Appeal's decision has been appealed to and heard by the Supreme Court of Canada, with a decision expected before the end of the year. If the Court were to endorse the respondent's position-which is essentially coextensive with the British Columbia Court of Appeal's findings - Aboriginal title claims would become extremely difficult to make out, perhaps further hindering the overall goal of the constitutional protection of Aboriginal rights in section 35 of the

\footnotetext{
${ }^{10}$ William at para 221.

${ }^{11}$ Ibid at paras 214, 219-239.

${ }^{12}$ Ibid at paras 165, 26.

${ }^{13}$ Ibid at para 165.
} 
Constitution Act, $1982^{14}$ : the reconciliation of historical Aboriginal and modern rights held under general Canadian law. ${ }^{15}$

The goal of this paper is to rehearse and critique the Court of Appeal's reasons for endorsing the respondent's site-specific model of sufficient occupation, and to offer an alternative method of answering the sufficient occupation question arising out of Delgaтииkw. Ultimately, it will be argued that the three arguments offered by the court do not, without more, establish that the site specific-model is any more desirable or jurisprudentially defensible than the one offered by the appellants.

Furthermore, it will be argued that either position misapprehends the nature of the occupancy test arising out the Supreme Court's decisions in Delgamuukw and Marshall; Bernard. The question of sufficient occupancy should be understood not by measuring a claim's concordance with an acceptable category of claims, site-specific or otherwise. Rather, it should be a fact-specific inquiry aiming to determine if the occupancy proven on the evidence comports with the broader and more fundamental goals of Aboriginal title. That is, the court must determine, on the facts, if the occupancy claimed is sufficient to warrant an overall finding that the claimant group's connection with the land is of central significance to the Aboriginal people making the claim.

The paper will proceed as follows. First, we will rehearse and critique each of the arguments for the site-specific model forwarded by the Court of Appeal in William. In addition to demonstrating that the site-specific model is not as tenable as the Court of Appeal suggests, our analysis will also reveal the error of attempting to parse questions of

${ }^{14}$ Constitution Act, 1982, being Schedule B to the Canada Act 1982 (U.K.), 1982, c.11 [“Constitution Act, 1982”].

${ }^{15}$ Brian Slattery, "The Metamorphosis of Aboriginal Title," The Canadian Bar Review, vol 85, 2006 pg 281 [Metamorphosis]. 
sufficient occupancy through categories of acceptable and non-acceptable title claims. Following this analysis, we will move to a constructive phase in which we suggest an alternative, flexible, and fact-specific standard for occupation, one which is consistent with the jurisprudential tests in Delgamuukw and Marshall; Bernard, and the broader reconciliatory goals of Aboriginal title.

We turn first to the Court of Appeal's reasons for endorsing the site-specific model. Emerging from the reasons are three distinct arguments, each of which the Court of Appeal seems to present as determinative of to the issue. These three arguments are adumbrated by the Court of Appeal in the following passage:

I also agree with the defendants that a territorial claim for Aboriginal title does not meet the tests in Delgamuukw and in Marshall; Bernard. Further, as I will attempt to explain, I do not see a broad territorial claim as fitting within the purposes behind s. 35 of the Constitution Act, 1982 or the rationale for the common law's recognition of Aboriginal title. Finally, I see broad territorial claims as antithetical to the goal of reconciliation, which demands that, so far as possible, the traditional rights of First Nations be fully respected without placing unnecessary limitations on the sovereignty of the Crown or on the aspirations of all Canadians, Aboriginal and non-aboriginal. ${ }^{16}$

The first argument is one of jurisprudential consistency, the claim being that a non-site specific claim (characterized as "territorial" in the above passage) does not satisfy the requirements set out in the previous leading cases on title. The Court of Appeal points to several passages in both Delgamuukw and Marshall; Bernard to substantiate this claim. On the contrary, and with respect, a careful analysis of these passages shows that this conclusion is not warranted.

\footnotetext{
${ }^{16}$ Supra note 1 at para 219.
} 
Consider first the passages highlighted from Delgamuukw that the Court of Appeal sees as strongly suggesting "that an intensive presence at a particular site was what the Court had in mind." ${ }^{\prime 17}$ The first, already reproduced above, goes as follows:

Physical occupation may be established in a variety of ways, ranging from the construction of dwellings through cultivation and enclosure of fields to regular use of definite tracks of land for hunting, fishing, or otherwise exploiting its resources ${ }^{18}$

The Court of Appeal emphasizes Lamer CJC's use of the word "definite" in Delgamuukw to draw its conclusion that specific, intensely used sites are the sufficient occupancy standard:

In particular, I note that the examples of title lands given at para. 149 are well-defined, intensively used areas. The reference to hunting, fishing, and other resource extraction activities is coupled with a specific description of the lands so used as "definite" tracts of land. I agree with British Columbia's assertion that what was contemplated were specific sites on which hunting, fishing, or resource extraction activities took place on a regular and intensive basis. ${ }^{19}$

The Court of Appeal's argument here, seems correct if one accepts, without more, that the Court's use of "definite" in this context meant something like specifically bound, particular sites under heavy use. On what is given in the passage directly above, this may be a plausible conclusion. However, the rest of the paragraph 149, not referenced by the Court of Appeal, weakens the claim:

In considering whether occupation sufficient to ground title is established, “one must take into account the group's size, manner of life, material

\footnotetext{
${ }^{17}$ William at para 220.

${ }^{18}$ Supra note 2 at para 149.

${ }^{19}$ William at para 221 [emphasis added].
} 
resources, and technological abilities, and the character of the lands claimed": Brian Slattery, Understanding Aboriginal Rights, at p. $758 .^{20}$

There are two things to note about the balance of the paragraph. First, the Court in Delgamuukw explicitly states that it is addressing the question of sufficient occupancy before setting out a list of factors to consider when determining sufficiency of any one claim of occupation. That is, Lamer CJC is actually telling us "what was contemplated," by providing interpretive guidance on the sufficiency occupancy issue. He does so by citing a list of factors given by Professor Slattery. Worryingly, the Court of Appeal, in conducting its analysis of the question for which the guidance is directed, fails to reference this guidance. Instead, it seizes upon one word of an earlier phrase to conclude that specific sites of intense use were contemplated. Rather providing evidence for its overall claim that Delgamuиkw strongly suggests a site-specific model, the passage relied on by the Court of Appeal fails to note that Lamer CJC actually states, and note merely suggests, how to go about answering the question at hand. These directions are ignored by the Court in its analysis.

The second salient point with regards to the unstated portion of para 149 is what the guidance itself tells us about the occupancy issue. Lamer CJC chose to provide a list of factors to inform a court's analysis of occupation, each of which will depend on the facts of a particular aboriginal group and claim area, and not on the nature of the claim itself. That is, the Chief Justice's concern does not mandate that a specific type of claim will succeed and others will fail. Rather, the factors listed could plausibly inform a court's discretion in deciding whether some factual instance of occupancy, not the nature of the claim as site-specific or of a certain intensity, will ground title.

${ }^{20}$ Supra note 2 at para 149 
Furthermore, if it is these various factors that are to inform a court's analysis of occupation, it seems inconsistent, or at least worrisome, for a court to simultaneously hold itself fast to accepting only intense site-specific claims. Group size, especially in instances of particularly large groups, may preclude clear boundary drawing, or at the least, make it difficult. Similarly, a group's manner of life, such as a nomadic or seminomadic style of living, may preclude the possibility of identifying bound specific sites, or of finding suitably intense use on any one understanding or standard. Similarly, material resources and the character of claimed lands may further make determinations of intense use difficult because of movements or changes necessitated by changes in climate, food, or available shelter. The panoply of contingencies that arise out of these factors make it difficult to accept that the court's role in answering the specificoccupancy question is to parse occupation into specific or territorial claims. Rather than suggesting that Delgamuиkw contemplated intense, site-specific uses, the factors outlined by the Chief Justice point more to a fact-specific, context bound inquiry. That is, it is more consistent to envision the court's role as exercising discretion when determining whether or not some one instance of occupation, on the facts, will be sufficient to ground title. At this point, we can say, confidently, that this particular paragraph, read in its entirety, does not support the Court of Appeal's conclusion that site-specific model of occupancy was contemplated.

We can now move to the second set of references to Delgamuukw which the Court of Appeal sees as endorsing a site-specific model. They are gestured to in this passage: 
might face in proving title is also telling. While, as the Court pointed out in Marshall; Bernard, there is no reason that semi-nomadic or nomadic groups would be disqualified from proving title, their traditional use of land will often have included large regions in which they did not have an adequate regular presence to support a title claim. That is not to say, of course, that such groups will be unable to prove title to specific sites within their traditional territories. ${ }^{21}$

The only explicit reference to nomadic peoples in Delgamuukw occurs at paragraph 139.

It follows Lamer CJC's discussion of the relationship between Aboriginal title and Aboriginal rights writ large, in which he states that s. 35(1) rights fall along a spectrum with regards to their degree of connection with the land. At one end of the spectrum sit activity rights wholly disconnected from particular areas of land, which protect a group's ability to engage in culturally integral practices, customs and traditions, as affirmed in $R v$ Van der Peet. ${ }^{22}$ As noted in $R v$ Adams, these certain activity rights may be more directly connected to the land, insofar as protection may be granted to engage in particular activities on specific tracts of land.$^{23}$ Finally, at the opposite end of the spectrum sits title itself, which is a right to the land itself. ${ }^{24}$ After making the spectrum-of-rights point, he makes the reference to nomadic peoples highlighted by the Court of Appeal:

Because aboriginal rights can vary with respect to their degree of connection with the land, some aboriginal groups may be unable to make out a claim to title, but will nevertheless possess aboriginal rights that are recognized and affirmed by s. 35(1), including site-specific rights to engage in particular activities. As I explained in Adams, this may occur in the case of nomadic peoples who varied "the location of their settlements with the season and changing circumstances" (at para. 27). The fact that aboriginal peoples were non-sedentary, however (at para. 27) does not alter the fact that nomadic peoples survived through reliance on the land prior to contact with Europeans, and further, that many of the practices, customs, and traditions of nomadic peoples that took place on the land

${ }^{21}$ William at para 222 [emphasis added].

22 [1996] 2 SCR 507 ["Van der Peet”].

${ }^{23}$ [1996] 3 SCR 101 ["Adams"].

${ }^{24}$ Delgamuukw at para 138. 
were integral to their distinctive cultures. ${ }^{25}$

From the reasons themselves, it is not immediately clear why the Court of Appeal finds this reference to nomadic peoples as a reason to endorse the site-specific model of title. Presumably, the court is suggesting that the reason why Lamer CJC would note that nomadic groups may face difficulty making it out title claims is because the court in Delgamuukw had a site-specific model of sufficient occupancy in mind. Though this tacit suggestion seems plausible, further consideration casts doubt on its strength.

The force of the Court of Appeal's argument begins to fade when we analyze the context in which Lamer CJC deploys the example of nomadic peoples. The Chief Justice uses the example after setting out the spectrum-like relationship between aboriginal rights writ large and any one right's connection with the land. The spectrum comments, in turn, form part of a discussion about the relationship between Aboriginal title and Aboriginal rights generally, ${ }^{26}$ not a discussion about what will be sufficient to ground title itself. The upshot of the paragraph is to demonstrate that rights and title are separable: that a failure to successfully show title does not preclude a finding of other rights. This is consistent with the overall finding of the court in Adams that a finding of title is not a necessary condition for a successful activity right claim. ${ }^{27}$ With an understanding of context then, it seems implausible to move, without more, to a conclusion that this reference to nomadic peoples is "telling" in the sense of suggesting that the Delgamuukw court had a sitespecific notion of title in mind. Rather, all that can be gleaned from the passage is the Supreme Court's recognition that title claims are separable from aboriginal rights claims.

\footnotetext{
${ }^{25}$ Ibid 139 [emphasis added].

${ }^{26}$ See Delgamuukw at paras 137-9.

${ }^{27}$ Supra note 23 at para 27.
} 
At this point, having shown that this second example does little to buttress the Court of Appeal's argument, we can move on to its third reference to Delgamuukw.

The reference to the third Delgamuukw passage is nuanced, and represents some subtle reasoning on the part of the Court of Appeal. Groberman J writes:

Finally, with respect to Delgamuukw, I note Lamer C.J.C.'s comments at paras. 150 and 151 dealing with the need for a group to demonstrate that a piece of land was of central significance to their distinctive culture. He considered this to be a "crucial" part of the test for Aboriginal title, but found that it was unnecessary to treat it as a specific element of the proof of title, because any land that met the other criteria for Aboriginal title would, of necessity, be of central significance to the culture. That position is a sensible one if the occupation needed to found a claim for title is sitespecific; it is not, however, if undifferentiated land within a large territory is to be included in a title claim. ${ }^{28}$

Here, the Court of Appeal is making an argument from internal consistency. Lamer CJC makes the statement that demonstration of the other criteria for title is sufficient to prove the crucial "central significance" requirement. The Court of Appeal argues that in order to make this statement intelligible, one of those other criteria, namely, sufficiency of occupancy, must be site-specific and not territorial. The unstated premise of this argument is that somehow, site-specific use itself indicates or is evidence of central significance. If we can accept that premise, and therefore, the former entails the latter, than the need for additional proof of the latter is redundant. Therefore, the Court of Appeal concludes, this passage indicates that the Delgamuukw court envisioned a sitespecific level of sufficient occupancy.

Again, as presented, the argument seems plausible. However, consider the relevant Delgamuukw passages referenced by the Court of Appeal in their entirety:

${ }^{28}$ Supra note 1 at para 223. 
In Van der Peet, I drew a distinction between those practices, customs and traditions of aboriginal peoples which were "an aspect of, or took place in" the society of the aboriginal group asserting the claim and those which were "a central and significant part of the society's distinctive culture" (at para. 55). The latter stood apart because they "made the culture of the society distinctive ... it was one of the things that truly made the society what it was" (at para. 55, emphasis in original). The same requirement operates in the determina- tion of the proof of aboriginal title. As I said in Adams, a claim to title is made out when a group can demonstrate "that their connection with the piece of land ... was of a central significance to their distinctive culture" (at para. 26).

Although this remains a crucial part of the test for aboriginal rights, given the occupancy requirement in the test for aboriginal title, I cannot imagine a situation where this requirement would actually serve to limit or preclude a title claim. The requirement exists for rights short of title because it is necessary to distinguish between those prac- tices which were central to the culture of claimants and those which were more incidental. However, in the case of title, it would seem clear that any land that was occupied pre-sovereignty, and which the parties have maintained a substantial connection with since then, is sufficiently important to be of central significance to the culture of the claimants. As a result, I do not think it is necessary to include explicitly this element as part of the test for aboriginal title. ${ }^{29}$

We can see Lamer CJC making several moves. First, he outlines the content of what I have called the central significance requirement, and its origins and importance in both in Van der Peet (with regards to activity rights) and Adams (with regards to Aboriginal title.) Next, he notes that though central significance requirement retains its salience in the test for title as a "crucial" element, the court need not treat it as a separate element of the test. He then offers his explanation for this difference: "it would seem clear that any land that was occupied pre-sovereignty, and which the parties have maintained a substantial connection with since then, is sufficiently important to be of central significance to the culture of the claimants." That is, the other elements of the title test, namely occupancy and the maintenance of a substantial connection, are sufficient

${ }^{29}$ Supra note 2 at paras $150-1$. 
grounds from which to infer central significance. This provides some support for what I called the Court of Appeal's unstated premise above: that site-specific use itself indicates central significance. Thus, this observation moves us towards being able to offer a justification of the Court of Appeal's conclusion that the central significance redundancy supports the site-specific view of occupancy.

However, as careful readers will have noticed, Lamer CJC's explanation of the central significance redundancy cites both the requirements of occupancy ("occupied presovereignty) and sustained temporal connection ("which the parties have maintained a substantial connection with since then"). That is, Lamer CJC's conclusion that the central significance requirement is redundant in the case of Aboriginal title is based on the combined presence of both elements of the title test. It seems, on a straightforward reading, that it is the combination of these two prongs that allows the Chief Justice to make an inference of central significance, not just the satisfaction occupancy requirement. This makes intuitive sense, as neither prong, on its own, could ground an inference to central significance. Tracts of land may be occupied regularly for various reasons which may not entail "central significance," for instance, a specific path used to move between two actually culturally significant sites. Similarly, substantial connection over time may be the product of necessity: for instance, a certain food source's affinity for a particular area, and be comopletely unrelated to the identity of a particular Aboriginal culture. Nothing about either of these features, on their own, point to central significance. However, as the Chief Justice notes, the presence of both occupation and significant connection sustained over time make the inference more reasonable. The upshot of all of this is simple: the Court of Appeal's conclusion that the redundancy of 
the central significance requirement with regards to title is evidence of a tacit site-specific understanding of occupancy cannot be substantiated on the evidence offered in Delgamuukw. The Chief Justice's explanation for the redundancy explicitly sites both occupancy and sustained temporality, and nothing else. Without more, the redundancy is no more "sensible" on a site-specific model rather than a territorial model.

If the foregoing is persuasive, we can now say that the Court of Appeal's finding that "several passages in Delgamuukw strongly suggest that an intensive presence at a particular site was what the Court had in mind"30 is not tenable. The first passage cited by the Court of Appeal, in which "definite" tracts of land were emphasized, did not point to a site-specific model of occupancy, to the exclusion of any other type of claim. The balance of the passage, which was not referenced by the Court of Appeal, offered explicit guidance about undertaking a fact-specific analysis of several particular factors to determine if sufficient occupancy was made out. Similarly, when considered in context, the second passage, far from endorsing a site-specific model of occupancy, serves to reinforce the separable nature of Aboriginal title and other section 35 rights, such as sitespecific rights and activity rights. Finally, the Court of Appeal's noting of Lamer CJC's comments about the redundancy of the central significance requirement does not support a site-specific understanding of title. Rather, it serves simply to emphasize that if the other requirements of title are made out, the inference to central significance can be satisfied. There is no reason why a site-specific model, rather than a more diffuse understanding of occupancy, would make the redundancy more "sensible."

\footnotetext{
${ }^{30}$ William at para 220.
} 
We can now move on to the Court of Appeal's discussion of title in Marshall; Bernard, which it holds "is even stronger in showing that Aboriginal title must be demonstrated on a site-specific rather than territorial basis. ${ }^{" 31}$ This is the second part of the Court of Appeal's larger, first argument that a non-site specific claim is inconsistent with the jurisprudence. Note also that the Court of Appeals claim is now categorical in character: title "must be demonstrated" via a site-specific basis, as opposed to the phrasing of the argument a few paragraphs earlier, where it said that "title cannot generally be proved on a territorial basis. ${ }^{, 32}$

Consider the Court of Appeal's reasons for this stronger finding drawn from

\section{Marshall; Bernard:}

Marshall; Bernard, as I read it, is even stronger in showing that Aboriginal title must be demonstrated on a site-specific rather than territorial basis. The majority expressly dealt with the question of whether hunting or fishing or the taking of other resources from land could found a title claim. At para. 58, it agreed that such activities could, where they were sufficiently regular and exclusive, be a basis for title. It also cautioned, however, that more typically, such activities will found only claims to specific Aboriginal rights.

The majority's equation of sufficient occupancy for Aboriginal title with the common law requirements to show title by virtue of possession is also important. It supports the views that title must be claimed on a sitespecific basis, and that a certain regularity and intensity of presence is needed before it will count as "occupancy". 33

Each of the above paragraphs contains one sub-argument. We shall consider each in turn.

\footnotetext{
${ }^{31}$ Ibid at para 224.

${ }^{32}$ Ibid at para 220 [emphasis added].

${ }^{33}$ Ibid at paras 224-5.
} 
In the first, the Court of Appeal holds that a certain observation of the Court at paragraph 50 of Marshall; Bernard affirms the necessity of a site-specific understanding of occupancy. Here is the Marshall paragraph in question:

It follows from the requirement of exclusive occupation that exploiting the land, rivers or seaside for hunting, fishing or other resources may translate into aboriginal title to the land if the activity was sufficiently regular and exclusive to comport with title at common law. However, more typically, seasonal hunting and fishing rights exercised in a particular area will translate to a hunting or fishing right. This is plain from this Court's decisions in Van der Peet, Nikal, Adams and Côté. In those cases, aboriginal peoples asserted and proved ancestral utilization of particular sites for fishing and harvesting the products of the sea. Their forebears had come back to the same place to fish or harvest each year since time immemorial. However, the season over, they left, and the land could be traversed and used by anyone. These facts gave rise not to aboriginal title, but to aboriginal hunting and fishing rights. ${ }^{34}$

The Court of Appeal has rightly recognized that the Supreme Court is advocating caution.

The courts must keep title and other Aboriginal rights distinct. However, there is a difference in the character of the caution and the conclusion that the Court of Appeal draws from it. Look again at McLachlin CJC's phrasing in Marshall; Bernard. After recognizing that certain resource-exploiting activities can ground title, she cautions that more typically, that is, more often than not, such activities will translate into a hunting or fishing right. She then offers three cases that exemplify this. The Court of Appeal, however, takes this caution to ground an equivocal, categorical conclusion that title must be demonstrated on a site-specific basis. This finding is not warranted. The Chief Justice's caution is given to emphasize the important distinction between title and other rights. The fact that caution is granted to keep these two concepts distinct, at a general level, does not license a conclusion that occupancy, a particular feature of the title test,

\footnotetext{
${ }^{34}$ Supra note 5 at para 58.
} 
must be understood as site-specific. Furthermore, the caution is that typically, and not always, resource-exploiting activities will ground activity rights and not title. This is consistent with the rest of Marshall; Bernard, which includes McLachlin CJC's finding that a nomadic claim's success for title always depends on whether the evidence brought satisfies the core elements of common law possessory title. ${ }^{35}$ Because a title claim's success is a function of whether a certain level of occupancy comports with the core of common law title, we cannot, as the Court of Appeal would have it, state that an entire class of potential claims - those deemed "territorial" - can never satisfy the occupancy requirement. The upshot of the foregoing, then, is that the Supreme Court's caution in Marshall;Bernard does not, as the Court of Appeal suggests, entail a categorical conclusion that sufficient occupancy must be site-specific. In fact, the Court of Appeal's conclusion is actually inconsistent with McLachlin CJC's test for title set out in

\section{Marshall; Bernard.}

The Court of Appeal offers a second argument in favour of the proposition that

Marshall; Bernard supports the view that title must be claimed on a site-specific basis:

The majority's equation of sufficient occupancy for Aboriginal title with the common law requirements to show title by virtue of possession is also important. It supports the views that title must be claimed on a sitespecific basis, and that a certain regularity and intensity of presence is needed before it will count as "occupancy". 36

Here, the Court of Appeal directly references McLachlin CJC's core-of-common-law title test, and holds that it "supports the view that title must be claimed on a site-specific basis." Once again, the Court of Appeal does not explicitly provide reasons why the

\footnotetext{
${ }^{35}$ Ibid at para 60.

${ }^{36}$ Supra note 1 at para 225.
} 
Supreme Court's equation of sufficient occupation with common law title supports that view. Presumably, the Court of Appeal is relying on a tacit premise. That is, that the core of common law possession has a certain level of specificity and regularity that could only be matched or satisfied by a site-specific claim. If we can accept that premise, then the argument goes through.

However, it is not clear that we should accept that premise. Common law possession is a notoriously slippery and Heraclitean concept. Consider the dizzying rules around adverse possession, or constructive possession, which make it difficult to say, with any certainty, what the requisite level of physical control is to ground a possessory claim. In fact, in Marshall; Bernard, the Chief Justice is very aware of the slippery nature of the concept: "possession at law is a contextual, nuanced concept." ${ }^{37}$ In fact, it is this recognition that leads McLachlin CJC to parse the question of sufficient occupancy into a factual analysis, not a conceptual determination of the cateogory of the claim: "the common law recognizes that possession sufficient to ground title is a matter of fact depending on all the circumstances, in particular the nature of the land and the manner in which the land is commonly enjoyed." ${ }^{38}$ Considering the foregoing, we should not accept the Court of Appeal's tacit premise that common law possession has a certain level of specificity and regularity.

Without this premise, we cannot accept the Court of Appeal's conclusion that McLachlin CJC's equation of occupancy with common law possession supports the view that sufficient occupancy requires site-specificity.

\footnotetext{
${ }^{37}$ Supra note 5 at para 66.

${ }^{38}$ Ibid at para 54.
} 
Far from the Court of Appeal's finding that territorial claim is inconsistent with the jurisprudence, our discussion of Marshall; Bernard shows us that it is inconsistent to rule such a claim out. McLachlin CJC's equation of sufficient occupancy with common law possession entails not a predetermined level of specificity or intensity, but the need for a careful and contextual analysis of the facts to determine if a particular occupancy will satisfy the "core" of common law possessory title.

At this point then, we can say that the Court of Appeal's first argument for sitespecificity, drawing on previous statements in Delgamuukw and Marshall; Bernard, is not tenable. Neither case, nor the combination of the two, provided defensible justifications for the conclusion that sufficient occupancy need be site-specific.

We can now move to the second argument offered by the Court of Appeal in favour of the site-specific understanding of sufficient occupancy, outlined in brief by Groberman J here:

I do not see a broad territorial claim as fitting within the purposes behind s. 35 of the Constitution Act, 1982 or the rationale for the common law's recognition of Aboriginal title. ${ }^{39}$

As the language suggests, this will be a purposive argument: the Court of Appeal aims to lay out its understanding of the telos of section 35 of the Constitution Act and the motivations for the recognition of title, and then argue that a territorial understanding of occupancy does not square with those purposes.

The Court of Appeal's understanding of the section 35 is that Aboriginal rights writ large, including Aboriginal title, have as their end or purpose the protection of

${ }^{39}$ William at para 219. 
Aboriginal people's cultural security and continuity. ${ }^{40}$ Aboriginal title then, is one particular type of culture-protecting right granting exclusive possession over traditional lands. The rationale for that protection is that in some instances, continued connection with the land itself is central to the culture's security and identity. As the Court of Appeal eloquently puts it earlier in the judgment, "If exclusive occupation is critical to the traditional culture and identity, then the law must recognize and protect aboriginal title. ${ }^{\prime 4}$ So, we can then say that the purpose of section 35 rights, broadly speaking, is the protection of Aboriginal cultural security and continuity, with Aboriginal title being one particular tool of protection.

However, the Court of Appeal does not follow the purposive argument through. After setting out what it takes to be the purpose of section 35 generally and title specifically, it does not offer reasons as to why, at the conceptual level, a non site-specific claim would not square with those purposes. Instead, the Groberman J turns to the facts of the Tsilhqot'in case and writes that "It is not clear to me, however, that the Tsilhqot' in culture and traditions cannot be fully respected without recognizing Aboriginal title over all the land on which they roamed." ${ }^{42}$ Now, we may be able to offer some findings from the Trial Judge which cast serious doubt on the factual accuracy of the Court of Appeal's statement, ${ }^{43}$ what is important for our purposes is that there is no argument given by the Court of Appeal which would support the proposition that a non site-specific claim would be inimical to the purposes of section 35 .

\footnotetext{
${ }^{40}$ Ibid at para 236.

${ }^{41}$ Ibid at para 171 [emphasis added].

${ }^{42}$ Ibid at para 232.

${ }^{43}$ For instance, see
} 
In fact, previous jurisprudence, including Delgamuukw, seems to suggest precisely the opposite. In his concurring opinion, La Forest J wrote that "aboriginal occupancy refers not only to the presence of aboriginal peoples in villages or permanently settled areas. Rather, the use of adjacent lands and even remote territories to pursue a traditional mode of life is also related to the notion of occupancy." ${ }^{44}$ That is, the relevance question for occupancy is, as the Court of Appeal itself notes, whether or not exclusive occupancy is critical to the groups 'cultural identity, ${ }^{45}$ or in La Forest J's terms, "way of life."

The Court of Appeal then shifts directions, and defends the site-specific understanding of occupancy by arguing against the plaintiff's characterization of it as a "postage stamp" view of title:

The fallacy in the plaintiff's characterization of the defendants' positions as representing a "postage stamp" view of Aboriginal title is that it ignores the importance of Aboriginal rights other than title in protecting traditional culture and lifestyles. ${ }^{46}$

The Court of Appeal's suggestion is that the "postage stamp" view of title is a cartographical straw man, which the Trial Judge proceeds to knock down. According to Griberman J, the "fallacy" is that in casting the site-specific view of title as postagestamp, the plaintiff's fail to recognize the possibility of connecting particularly intensely used areas with broader areas in which certain other Aboriginal rights can be exercised. ${ }^{47}$ That is, we can connect the site-specific title areas with activity rights in order to achieve the goals of section 35 . Groberman $\mathrm{J}$ puts it this way:

\footnotetext{
${ }^{44}$ Supra note 2 at para 199.

${ }^{45}$ Supra note 1 at para 171

${ }^{46} \mathrm{Ibid}$ at para 234.

${ }^{47}$ Ibid at para 238.
} 
The result for semi-nomadic First Nations like the Tsilhqot'in is not a patchwork of unconnected "postage stamp" areas of title, but rather a network of specific sites over which title can be proven, connected by broad areas in which various identifiable Aboriginal rights can be exercised. This is entirely consistent with their traditional culture and with the objectives of s. $35 .^{48}$

This argument is quite deft. Although it does not support the Groberman J's overall argument that a non site-specific model of title does not fit with the goals of section 35 , it does show that those goals can possibly achieved through the use of all of the various constitutional protections available under section 35 . We should note this and be aware of the possibility of such an occurrence. However, we can say, in reply, two things. First, that the factual findings of the Trial Judge do seem to suggest that a broader view of title over the "proven" claim area would be necessary for the proper protection of the Tsilhqot' in culture. ${ }^{49}$ Connection with the land in the Claim Area itself was, in many respects, critical to the inherited cultural identity of the appellants. Second, that the court in Delgamuukw cautioned against reducing Aboriginal title to a bundle of activity rights for strictly traditional customs and traditions: we must not think we can always supplement the value of title by granting narrow activity rights which may amount to "a legal straitjacket on aboriginal peoples who have a legitimate claim to the land." ${ }^{, 50}$ The Court of Appeal's alternative suggestion, in which a series of activity rights are linked by limited areas of aboriginal title, may end up functioning as a legal straitjacket to the Tshilqot'in way of life.

\footnotetext{
${ }^{48}$ Ibid.

${ }^{49}$ See Trial Judgment at paras 612-613, 660-62.

${ }^{50}$ Supra note 2 at para 132.
} 
With the foregoing said, we can now say that the Court of Appeal has not provided us a persuasive purposive argument for a site-specific picture of title. As Groberman J himself emphasized, the telos of title is to protect exclusive occupation where that occupation is critical to the cultural identity of Aboriginal peoples. ${ }^{51}$ The sufficient character or quality of that occupation should be indexed to the cultural significance of the occupation, not a narrow categorization of acceptable precision.

The final argument offered by the Court of Appeal for its dismissal of the "territorial" model is an argument from reconciliation. That is, the Court of Appeal argues that the site-specific model is concordant with the broad goal of reconciling Aboriginal rights and wider Canadian interests, and that any more diffuse, non sitespecific interpretation does not further the reconciliatory imperative. As Groberman $\mathbf{J}$ writes of the site-specific view:

It seems to me that this view of Aboriginal title and Aboriginal rights is fully consistent with the case law. It is also consistent with broader goals of reconciliation. There is a need to search out a practical compromise that can protect Aboriginal traditions without unnecessarily interfering with Crown sovereignty and with the well-being of all Canadians. As I see it, an overly-broad recognition of Aboriginal title is not conducive to these goals. Lamer C.J.C.'s caution in Delgamuukw that "we are all here to stay" was not a mere glib observation to encourage negotiations. Rather, it was a recognition that, in the end, the reconciliation of Aboriginal rights with Crown sovereignty should minimize the damage to either of those principles. $^{52}$

The argument seems to run as follows. The Court of Appeal first outlines what it takes to be the "broader goal of reconciliation," that is, the reaching of a practical compromise which on the one hand, protects Aboriginal traditions, while at the same time not

\footnotetext{
${ }^{51}$ Supra note 1 at para 171.

${ }^{52}$ Ibid at para 239.
} 
unnecessarily interfering with Crown sovereignty and the welfare of Canadians writ large. If we take "principles" in the last sentence to be referring to the Aboriginal and non-Aboriginal interests in tension, then the Court of Appeal is also suggesting that such a compromise should aim to limit the damage to both sets of concerns. To sum up then, Groberman $\mathrm{J}$ is forwarding a picture of reconciliation as a process of coming to a pragmatic arrangement that respects and minimally impairs the interests in tension or conflict. We can call this premise (1):

(1) In the context of Aboriginal rights, reconciliation is a process of coming to a pragmatic arrangement or practical compromise respecting and minimally impairing the Aboriginal and non-Aboriginal interests engaged.

Groberman J's next move is to argue that an overly-broad recognition of title, that is, what the Court of Appeal sees as following from an endorsement of the "territorial" understanding of sufficient occupancy, would hinder the possibility of achieving reconciliation. Presumably, though this is not stated, this is because an overly-broad recognition of title would lead to more title claims being made out in such a manner as to "minimally impair" any non-Aboriginal interests in play. As an unstated corollary, a more narrow, site-specific interpretation would lead to less impairment of third party interests. So, we can state the Court of Appeal's second premise as follows:

(2) A territorial or non-site-specific understanding of sufficient occupancy would increase the number of defensible Aboriginal title claims, and thus unnecessarily damage non-Aboriginal interests.

This leads us to the Court of Appeal's conclusion:

(3) From (1) and (2), it follows that we should not endorse a non site-specific interpretation of sufficient occupancy, because it is not consistent with minimalimpairment goal of reconciliation.

Premises (1) and (2) of this simple argument, as stated, do not, without more, entail the 
conclusion in (3). What is missing from premise (2) is an explanation of how an increase in the number of title clams granted actually damages third party interests. We need to add an additional, and perhaps obvious, unstated premise: that judicial recognition of Aboriginal title automatically entails an enforcement of that title. Automatic and total enforcement of one set of interests would be no 'reconciliation' indeed, as it would not minimally impair both principles. Rather it would wholly privilege the Aboriginal claim over the non-Aboriginal claim. If recognition of title entails complete enforcement of a superior claim (that is, Aboriginal title over a Crown or third-party claim) then the Court of Appeal's conclusion is warranted, and it their rejection of the territorial model remains sensible.

However, we do not have to accept this unstated premise. There is a way to separate juristic recognition of title and its complete enforcement. To explain, we must first rehearse an argument from Professor Slattery.

In the Metamorphosis, Professor Slattery has argued that the common law of Aboriginal title, like the common law generally, has evolved alongside important societal changes ${ }^{53}$ Common law Aboriginal title, in its original form, which Professor Slattery calls "historical title," recognized that Aboriginal nations living under the protection of the Crown had a defensible possessory right to lands not ceded to the Crown, with the traditional remedy being expulsion of those occupying such lands ${ }^{54}$ This title is first

\footnotetext{
${ }^{53}$ Supra note 15 page 259.

${ }^{54}$ Ibid page 260, 262.
} 
recognized in the Royal Proclamation of $1763,{ }^{55}$ a document which itself is indexed to the particular and largely insular relationship between Aboriginals and Crown settlement communities which existed at the time. Professor Slattery calls the common law principles that arose out of the assertion of sovereignty and were manifest in the Royal Proclamation the "Principles of Recognition." Professor Slattery notes that although the provisions of the Proclamation were reasonably well-adapted to the circumstances at the time of drafting, they became "increasingly inadequate to deal with the changed situation of Indigenous peoples and consequently underwent a significant transformation," 56 becoming what Professor Slattery terms the "Principles of Reconciliation:"

Given this new reality, the common law did not remain idle but adapted to take account of the change in circumstances. The adaptation was shaped by three needs: to ensure the continuity of aboriginal title and its recognition in a modern form; to supply appropriate remedies for the wrongs visited on Indigenous peoples; and to accommodate public and private interests in the lands concerned. These needs gave rise to common law Principles of Reconciliation, which supplemented and modified the traditional Principles of Recognition applying at the time of Crown sovereignty. ${ }^{57}$

That is a new body of common law around title has emerged. Whereas the Principles of Recognition govern the nature and scope of aboriginal title at the time of Crown sovereignty, the Principles of Reconciliation govern the legal effects of title, in modern times. ${ }^{58}$ The most important effect of these new principles is that they transform historical title, a static right, into what Professor Slattery calls a "generative right," that is, one that exists in a dynamic or latent form, "capable of particular articulation by the courts, but

${ }^{55}$ Royal Proclamation of 7 October 1763, in Clarence S. Bringham, ed., British Royal Proclamations Relating to America (Worcester, Mass: American Antiquarian Society, 1911), 212 [“Proclamation"].

${ }^{56}$ Supra note 15 page 261.

${ }^{57}$ Ibid page 262.

${ }^{58}$ Ibid page 282. 
whose full implementation requires agreement between the Indigenous party and the Crown." ${ }^{59}$ That is, the role of the court is to recognize core elements of a generative, right, enough to provide a foundation for negotiations and to ensure that the Indigenous party enjoys a significant portion of its rights pending the final agreement. ${ }^{60}$

The Principles of Recognition, then, function to signal the court's acknowledgement of the legitimacy of an Aboriginal group's title claim, grounded in the relationship between the group and the land in question. The Principles of Reconciliation "take as their starting point" the former, but also consider other factors, such as the later history of the land, the Indigenous group's contemporary interests, and third party and societal interests. ${ }^{61}$ They then partially implement title as a generative right, and leave it to the parties to completely instantiate the right through a treaty or other negotiating process.

We are now in a position to return to our original point, that we need not assume that the recognition of Aboriginal title automatically entails its full enforcement, and thus, that we should not accept the Court of Appeal's argument from reconciliation for sitespecific occupancy. Professor Slattery argues that if we fail to distinguish between these two sets of principles, "we may fall into the trap of assuming that historical aboriginal title gives rise automatically to modern title, without regard to its broader social impact. ${ }^{62}$ " This is precisely what the Court of Appeal has done in its reconciliation-based argument for the site-specific model. In fact, Professor Slattery predicts this kind of

\footnotetext{
${ }^{59}$ Ibid page 262.

${ }^{60}$ Ibid.

${ }^{61}$ Supra note 15282.

${ }^{62}$ Ibid [emphasis added].
} 
finding explicitly:

Unless we distinguish between these two sets of principles, we may fall into the trap of assuming that historical aboriginal title gives rise automatically to modern title, without regard to its broader social impact. Such an assumption fosters two judicial tendencies. The courts may be led to construe historical aboriginal title in an artificially restrictive way, in the effort to minimize conflicts with modern societal and third party interests. Alternately, an expansive view may be taken of the processes whereby historical title is extinguished, whether by Crown action or the passage of time. $^{63}$

We can see the Court of Appeal engaging in this kind of artificially restrictive construction of title at precisely this juncture. Failing to appreciate that recognition of title does not entail complete enforcement, and thus attempting to avoid a misperceived automatic derogation of non-Aboriginal interests, the Court argues for a narrower understanding of title, that is, one that is site-specific. This artificial narrowing, Professor Slattery argues, is detrimental:

These tendencies, if left to operate unchecked, will diminish the possibility of reconciliation ever occurring. For the successful settlement of aboriginal claims must involve the full and unstinting recognition of the historical reality of aboriginal title, the true scope and effects of Indigenous dispossession, and the continuing links between an Indigenous people and its traditional lands. ${ }^{64}$

The emphasis here is on the fact that an integral part of reconciliation is the fulsome and honest recognition, by the court, of several important realities. First, the court must stipulate the reality of historical title; second, the court must appreciate the true breadth and depth of the historical dispossession of Aboriginal lands; third, the court must acknowledge the potential profoundness of the persisting connection between Aboriginals and traditional lands. Reconciliation must be "full and unstinting." Anything

\footnotetext{
${ }^{63}$ Ibid [emphasis added].

${ }^{64}$ Ibid [no emphasis].
} 
less, including the artificial narrowing of the concept of title, is an indignity to the Indigenous people's whose legitimate claims persist. As Professor Slattery remarks, to limit our recognition of the scope and force of these claims is to "rub salt into open wounds. ${ }^{.65}$

Had the Court of Appeal been alive to the distinction between the Principles of Reconciliation and the Principles of Recognition, it would not have made the argument from reconciliation. The conclusion of that argument, that the sufficient occupancy requirement be interpreted in a narrow, site-specific manner, does not facilitate the goal of reconciliation. Rather, it frustrates it. Far from providing a foundation for a meaningful compromise that respects the historical and legal realities of aboriginal title, while giving due consideration to the modern rights holders, a site-specific model, from the outset, belittles and deflates the doctrine of aboriginal title. On this point then, we can reject the Court of Appeal's argument for site-specificity from reconciliatory grounds.

At this point, we have extensively canvassed, reconstructed, and criticized each of the Court of Appeal's arguments for the respondent's understanding of sufficient occupancy. If the foregoing it is correct, we should not endorse the Court's overall conclusions that a more diffuse, non-site specific model is either (i) inconsistent with previous jurisprudence, (ii) inimical to the purposes of section 35 , or (iii) inconsistent with the broader goals of reconciliation. As a result, we should not, as the Court of Appeal has held, find that in order to ground an Aboriginal title claim, one must forward a clearly defined, intensely used tract of land.

\footnotetext{
${ }^{65}$ Ibid.
} 
But what should be the standard for occupation? It seems intuitive to suggest that we offer the opposite view: that a territorial, or non-site specific model be forwarded as sufficient. The truth of the matter is, however, that none of the arguments above have actually shown that the appellant's model is correct. Rather, the foregoing has established that the jurisprudence does not preclude the success of a title claim that is not sitespecific. That is, among the set of possible, jurisprudentially defensible title-grounding claims, there are at least some which are not site-specific.

What all of this goes to show, I think, is that to ask what 'category' of claim will be sufficient is to ask the wrong question. Terminological side-taking isn't all that helpful to the parties making their arguments, or to the court. We may become cumini sectores, splitting hairs (or categories) that, in the end, do not aid in answering the central question at hand. The central question - whether a particular mode of occupation will satisfy a title claim - comes out of a pithy statement of the law's central concern. This statement comes out of the Court of Appeal's discussion about aboriginal title generally:

The law must recognize and protect aboriginal title where exclusive occupation of the land is critical to the traditional culture and identity of an Aboriginal group. ${ }^{66}$

The first clause of the sentence recognizes a kind of imperative or duty. The court must both 'recognize' and 'protect' aboriginal title. This echoes the language of section 35 of the Constitution Act, 1982, while at the same time adding a more active verb, 'protect,' in place of the constitution verb of 'affirm.' More interesting though is the Court of Appeal's description of when this duty to recognize and protect is engaged. That is, it provides a simple, and yet powerful evaluative standard. The benefits and burdens of title

${ }^{66}$ Supra note 1 at para 172. 
are triggered where exclusive occupation of the land is critical to the traditional culture and identity of an Aboriginal group. Title tracks a particular attachment: the strength of a people's connection with their land, such that that connection itself forms a significant part of their collective identity. This attachment itself, once recognized, is what justifies the acknowledgement of the right to the land and the imposition of its correlative duties and obligations on others. As recognized by Professor Slattery:

It is the strong spiritual, legal, and material bonds that Indigenous peoples hold with their lands that animate aboriginal title and supply its underlying rationale. ${ }^{67}$

If it is these bonds which animate and justify Aboriginal title, then perhaps it is these bonds we should look to in answering our standard of occupancy question. Perhaps, when asking the question of whether or not one instance of occupation is sufficient to ground title, we should not debate about what category of use will be sufficient, but rather whether the facts of that instance of occupation can establish the critical connection between the land and a group's cultural identity. If our goal in recognizing and affirming a group's right to exclusive occupation is to protect the cultural identity of those groups, it is a mistake to ask whether their occupation of the land meets some abstract and predetermined category of sufficiency. Rather, we must ask if their exclusive occupation, understood from their perspective is essential to who they are as a people. The question would not be, does their occupation fall into a category of "sufficient" occupation? Rather, do the facts of their occupation demonstrate a connection with the land essential to their identity? Or, to put it another way, does the evidence satisfy the crucial "central

${ }^{67}$ Supra note 15 page 274. 
significance" requirement for title? Is the group's connection with the land of a central significance to their culture ${ }^{68}$

To more succinctly state the upshot of the above paragraphs: to parse sufficient occupancy along predetermined categories of possession as "good enough" or insufficiently precise is to misdirect our attention. I suggest that our analysis of sufficient occupation should be consistent with the overall goal of title granting, that is, recognize and protect instances of exclusive occupation where that occupation is critical or crucial to the cultural identity of the claimant group. None of the variables considered by the site-specific/territorial debate actually point, themselves, to such a connection. They are good indicators of such a connection, and may signal the presence of such a connection, they cannot be enough to ground an inference to the kind of bond that title is meant to protect. Specificity of boundaries and intensity of use are themselves, just descriptions, which may or may not accompany the profound connection between land and cultural identity that title contemplates. What would ground such a claim are the kinds of qualitative, historical, moral, and spiritual arguments given by those witnesses called by the appellants in William. It is these direct connections which must be our focus when wondering about whether an occupation was sufficient for title.

Again, our question should be: have the claimants provided evidence which demonstrates that their exclusive occupation of the land is central or critical to their collective identity as a people? In addition to being more congruent with the goal of aboriginal title overall, such a line of inquiry would be preferable to the territorial/sitespecific discourse on the question for the following reasons:

${ }^{68}$ Supra note 23 at para 26; see also Delgamuukw at paras $150-151$. 
First, this method of analysis is consistent with the jurisprudence. A court's answer to this question will be, of necessity, fact-specific: the court must look to the evidence provided and decide if the crucial cultural identity and land connection contemplated by Aboriginal title is present. This will require an analysis of the kinds of factors suggested by Professor Slattery and affirmed by Lamer CJC as a guide to the occupancy question in Delgamuukw. ${ }^{69}$ Courts must consider the group's size, it's manner of life, resources and technological abilities, and the character of the lands claimed. It also squares with McLachlin CJC's holding that finding title in cases of nomadic or seminomadic peoples -which, by definition, are likely to be "territorial" in nature - "depends on the evidence." 70

Second, this line of inquiry provides plausible answers for two additional lingering questions in the jurisprudence on Aboriginal title. First, it provides a more tenable explanation for the redundancy of the central significance requirement. Recall that Lamer CJC held that the requirement that aboriginal activity rights be those that were "a central and significant part of the society's distinctive culture" also operates in a title claim. However, unlike the Van der Peet test for activity rights which explicitly requires a demonstration of an activity's central significance, such an explicit demonstration is not required in title analysis because the occupancy requirement for title makes it redundant. $^{71}$ As rehearsed above, Lamer CJC held that when the two prongs of the occupancy requirement (occupation and the maintenance of a substantial connection) were satisfied, one could infer central significance. Recall also that we argued that

\footnotetext{
${ }^{69}$ Supra note 2 at para 149.

${ }^{70}$ Supra note 5 at para 66.

${ }^{71}$ Supra note 2 at para 150.
} 
neither of those prongs, in themselves, provide us with any ground for finding central significance. ${ }^{72}$ As a result, we may be left unsatisfied and unwilling to accept that central significance is really entailed by the occupation requirement so understood.

That worry disappears on our proposed understanding of the occupancy question as a fact-specific inquiry seeking evidence of central significance. If we understand sufficient occupancy as occupancy which, on the facts, demonstrates central significance, the redundancy noted by the Chief Justice makes perfect sense. We need not ask about whether or not a claimed land has central significance to a group's cultural identity during a title claim, because one aspect of the test for that claim, namely, the occupancy requirement, itself aims at finding central significance.

In addition to offering a better explanation of the noted redundancy, our centralsignificance understanding of occupation may provide a concrete opportunity for the Court to consider the "Aboriginal perspective" during an analysis of title claim. The importance of taking the Aboriginal perspective on land into account was affirmed in

\section{Delgamuukw:}

This debate over the proof of occupancy reflects two divergent views of the source of aboriginal title. The respondents argue, in essence, that aboriginal title arises from the physical reality at the time of sovereignty, whereas the Gitksan effectively take the position that aboriginal title arises from and should reflect the pattern of land holdings under aboriginal law. However, as I have explained above, the source of aboriginal title appears to be grounded both in the common law and in the aboriginal perspective on land; the latter includes, but is not limited to, their systems of law. It follows that both should be taken into account in establishing the proof of occupancy. ${ }^{73}$

\footnotetext{
${ }^{72}$ See pages 13,14 of this paper.

${ }^{73}$ Supra note 2 at para 147 [emphasis added].
} 
Indeed, Lamer CJC goes further and holds that true reconciliation of aboriginal and nonaboriginal interests in land will require that our analysis of occupation and exclusivity place equal weight on both perspectives. ${ }^{74}$ Taking up the aboriginal perspective includes, but is not limited to, referencing a claimant group's system of law. ${ }^{75}$

Our central-significance understanding of occupancy provides one substantive way in which the Aboriginal perspective can be taken into account during title analysis. As argued above, the court would have to consider cultural-historical evidence that could substantiate a finding that exclusive occupation of the land was crucial to the cultural identity of the claimant group. This evidence would include the Aboriginal group's understanding of its own practices, traditions, and written and oral histories that speak to such a connection. That is, a judicial determination of sufficient occupancy would require the court's appreciation of the Aboriginal group's view of their own interest in the land. Thus, our non-category based, central-significance understanding of the occupancy requirement is not only consistent with the previous leading jurisprudence, it also adds to it by filling some gaps of uncertainty in the existing case law.

To conclude, we have taken some small strides in understanding the conceptual and practical hornet's nest that is Aboriginal title. Further, we have provided reasons for not adopting the Court of Appeal's narrow interpretation of sufficient occupancy, and suggested that the whole site-specific/territorial debate is orthogonal to the central question at hand. Realizing this, we offered an alternative line of inquiry for determining specific occupancy, one that is fact-specific and indexed to a connection of central significance between a land claim and the cultural identity of the claimant group.

\footnotetext{
${ }^{74}$ Ibid at para 156.

${ }^{75}$ Ibid at para 147.
} 
Sometimes, it pays to remember what one's purpose is. A reminder that title protects exclusive occupation where that occupation is of critical value to a group's identity, to who they are as a people, can refocus our energies towards ascertaining the character of the connection between people and the land. That connection, as suggested on historical and cultural facts, is what the specific occupancy requirement should be indexed to. 